\title{
Reformatorische ambtstheologie en de eigenheid van mannen en vrouwen
}

\author{
J. Hoek en R.T. te Velde
}

\begin{abstract}
This article responds to dr. Harmen Jansen's critique of the classic Reformed position on women in office, as maintained by the Gereformeerde Bond in the Protestant Church of the Netherlands. While men and women are created equal in God's image, and thus share equally in Christ's salvation, this does not exclude a functional difference in task and responsibility. An appeal to cultural and social patterns should not relativize Scripture's authoritative teaching. The church welcomes the participation of women and their Spirit-given talents in various ministries, even if the offices of pastor and elder remain closed to them. The dynamics of mutual dedication and love that mirrors the relationship of Christ and his church can only function if the distinct identities of men and women are preserved.
\end{abstract}

\section{Nodig en open gesprek}

In januari 2020 verscheen een appèl van enkele (oud-)synodeleden van de Protestantse Kerk in Nederland: 'Laat in de Protestantse Kerk de ambten kerkbreed voor vrouwen opengaan!'1 De slotzin van dit appèl luidt: 'Maak een einde aan te gemakkelijk conservatisme dat zich telkens weer verschuilt achter een paar eenzijdig geïnterpreteerde Bijbelteksten en aanvechtbare theologische redeneringen over mannelijke eigenschappen die noodzakelijk zouden zijn voor de bediening van Woord en sacrament of het leiding geven in de Kerk!'

Het artikel van dr. Jansen waarop wij - op verzoek van de redactie - reageren, kan worden beschouwd als een nadere theologische onderbouwing van dit appèl. De kern van Jansens betoog is dat in de 'traditionele' visie zoals onder andere verwoord in de brochure van de Gereformeerde Bond

1 Dit appel was ondertekend door ds. Harmen Jansen, ds. Peter Breure, Bernard van Delft, Peter Goudkamp, Bert Teerink en ds. Robert Wiltschut. Het appel is onder meer te lezen op de website van dr. Jansen: https://www.harmenjansen.nl/?p=2294 (geraadpleegd 4 maart 2021). Een reactie vanuit de leiding van de Protestantse Kerk werd geplaatst op https://www.protestantsekerk.nl/verdieping/kerkelijk-spreken-over-de-vrouw-in-het-ambt/ (geraadpleegd 4 maart 2021). 
Mannelijk en vrouwelijk schiep Hij hen ${ }^{2}$ een onjuiste verknoping plaatsvindt tussen 'scheppingsordeningentheologie' en 'ambtstheologie', via de notie van 'regeermacht' die exclusief aan mannen zou toekomen en verbonden wordt met 'leiding' en 'gezag' van ambtsdragers in de kerk.

Wij vinden het van groot belang dat het gesprek over deze zaak niet stokt, maar goede voortgang vindt. We realiseren ons dat vrouwen er inderdaad pijn aan lijden dat de toegang tot de kansel en het ambt van predikant hun in de praktijk in een deel van de Protestantse Kerk wordt ontzegd, terwijl er kerkordelijk geen enkele hinderpaal is. We kennen verschillende van deze vrouwen. We weten ook dat veel vrouwen in de wereldkerk zegenrijk bezig zijn in het ambt van predikant en dat dit geldt voor nog veel meer vrouwen die de ambten van ouderling of diaken bekleden. De Heilige Geest maakt kennelijk van hun diensten gebruik en vele gemeenten hebben veel aan deze vrouwen te danken. Deze waarneming laten we voorlopig even staan naast de traditionele visie die de inzet van vrouwen in de kerk niet in de vorm van ambtelijke dienst mogelijk acht. Voldoende redenen om de argumentatie van Jansen c.s. serieus te nemen. Daarom pakken we de toegeworpen handschoen op. Hierbij identificeren we onze positie niet zonder meer met het betoog in de brochure Mannelijk en vrouwelijk schiep Hij hen. Wel vinden we dit een belangrijk document, zeker in samenhang met de vervolgbrochure Geroepen vrouw. ${ }^{3}$

Het zal wel om een gesprek in gelijkwaardigheid dienen te gaan. Doel van het gesprek moet zijn om met elkaar dieper te peilen, bredere verbanden te leggen en overstijgende inzichten te ontwikkelen. Eerlijk gezegd achten we de geciteerde bewoordingen uit het Appel daartoe niet bepaald behulpzaam. Wie de gesprekspartner beschuldigt van te gemakkelijk conservatisme, eenzijdige interpretatie van bijbelteksten en aanvechtbare theologische redeneringen, zet de zaak meteen op scherp. Dat gebeurt ook wanneer Jansen aan het begin van zijn artikel uitspraken van de WCRC citeert die een naar onze smaak onaangename framing aanbrengen. Het is zeer de vraag of machtswoorden als 'discriminatie' en 'roof van waardigheid' helpen om in een open dialoog met elkaar tot beter inzicht te komen. Van onze kant achten we het onjuist wanneer elke honorering van diversiteit tussen man en vrouw bij de invulling van de bearbeiding van de gemeente als discriminerend wordt

2 Mannelijk en vrouwelijk schiep Hij hen. Over man, vrouw en ambt. Uitgave vanwege het hoofdbestuur van de Gereformeerde Bond in de Protestantse Kerk in Nederland, Apeldoorn 2012 (auteur P.F. Bouter).

3 Geroepen vrouw. Vrouwen in Christus' gemeente. Uitgave vanwege het hoofdbestuur van de Gereformeerde Bond in de Protestantse Kerk in Nederland, Apeldoorn 2015 (auteurs M. van Campen en J. Hoek). 
gekwalificeerd omdat deze de waardigheid van de vrouw zou aantasten. Omgekeerd wijzen we even helder de gedachte af dat vrouwen zouden mogen worden geweerd uit de ambten op basis van louter biologische en psychologische overwegingen.

Om te beginnen geven we de hoofdlijnen weer van de beide genoemde brochures die representatief zijn voor de actuele positie van het hoofdbestuur van de Gereformeerde Bond in de Protestantse Kerk in Nederland. In deze publicaties wordt namelijk een breed bijbels en praktisch-theologisch kader geschetst, waarvan een groot deel in het artikel van Jansen niet aan bod komt. Vervolgens analyseren we hoe Jansen hierop reageert, om af te sluiten met een eigen positiebepaling en met enkele aanzetten voor voortgaand gesprek. Hoewel de aanleiding voor dit artikel ligt bij een Appel aan het adres van de Gereformeerde Bond, gaat de discussie over 'vrouw en ambt' ook andere kerken in de gereformeerde gezindte aan. De afgelopen decennia kwamen de Nederlands Gereformeerde Kerken en de Gereformeerde Kerken vrijgemaakt tot een openstelling van alle ambten voor vrouwen, terwijl de Christelijke Gereformeerde Kerken, de Hersteld Hervormde Kerk en de Gereformeerde Gemeenten vasthouden aan alleen mannelijke ambtsdragers.

\section{Mannelijk en vrouwelijk schiep Hij hen}

In Mannelijk en vrouwelijk schiep Hij hen wordt stelling genomen tegen het gelijkheidsdenken dat onze huidige westerse cultuur stempelt. 'Vanuit ons culturele gevoel van gelijkheid is het onrecht wanneer A niet mag wat B wel mag, alleen op grond van geslacht, ras of godsdienst.'4 Dit gelijkheidsdenken wordt gekwalificeerd als een breuk met het bijbelse denken. Twee mensvisies staan tegenover elkaar. Vanuit de idealen van de Franse Revolutie zijn man en vrouw gelijke individuen met gelijke rechten. Vanuit de Schrift gezien zijn man en vrouw beiden gelijkwaardig naar Gods beeld geschapen, maar met verschillende posities die elkaar aanvullen. De kerk moet op dit punt de vervreemding van de cultuur als onvermijdelijk aanvaarden 'omdat het denken van de Bijbel over man en vrouw wezenlijk tot de openbaring behoort. Het is een orde die ons van Godswege is gegeven. Hier geldt iets van: "U geheel anders..."

Het betoog in de brochure kent de volgende stappen: eerst worden bijbelse gegevens op een rij gezet, vervolgens worden ambtstheologische overwegingen gegeven en ten slotte passeert een aantal bijkomende argumenten om de ambten niet voor vrouwen open te stellen de revue.

4 Mannelijk en vrouwelijk, 41. 
(1) In het Oude Testament ziet de brochure meteen vanuit de eerste hoofdstukken van Genesis als grondlijn getekend dat man en vrouw samen zijn bedoeld om Gods beeld te zijn. De vrouw staat als 'hulp tegenover' naast de man. Daarmee is geen verschil in waarde aangegeven, want man en vrouw zijn gelijkwaardig naar Gods beeld geschapen. De vrouw vindt haar levensdoel en bestemming in de toewijding aan en aanvulling van de man. De man geeft liefdevol leiding als eerst verantwoordelijke en zo is er een prachtige harmonie en eenheid. Dit is de scheppingsorde ten aanzien van de manvrouwverhouding. De glans van deze orde verdwijnt echter grotendeels door de zondeval en de gevolgen daarvan. In Genesis 3:16 klinkt de gebrokenheid door: 'Als een straf en noodverband stelt God het heersen. Later zal dat "heersen" van de man in de geschiedenis regelmatig ingevuld worden vanuit het kwade in de mens, waaronder de vrouw veel en bitter geleden heeft. Tegelijk blijft de inzetting van Genesis 3 een werk van God om de eenheid tussen man en vrouw te bewaren.' ${ }^{5}$ Vanuit het grondleggend onderwijs in Genesis 1-3 wordt deze lijn door heel het Oude Testament heen doorgetrokken.

In het Nieuwe Testament zien we hoe Jezus de vrouw benadert met heilige liefde en opzoekende goedheid. Zijn verlossingswerk verbindt Hij nauw met een terugkeer tot de oorspronkelijke bedoelingen van God in de schepping (zie bijv. Matth. 19:1-12). 'Voor Zijn gevolmachtigde apostelen verkiest Christus twaalf mannen, omdat deze taak past bij de positie waartoe de man bestemd is.' 6

$\mathrm{Na}$ Pinksteren deelt de Heilige Geest aan mannen en vrouwen vele charismata uit. 'De apostel drukt klip en klaar uit dat het verlossingswerk van de Zoon van God bestemd is voor man en vrouw, zonder onderscheid. Gods liefde roept beiden het eeuwige leven binnen om hen beiden tot Zijn geliefde kinderen aan te nemen. ${ }^{7}$ (Gal. 3:28b). Niettemin wordt de leiding van de gemeente aan mannen voorbehouden. 'De Heilige Geest moet zich voegen naar de inzetting van God in het begin van de schepping en zondeval. De Heilige Geest moet zich in dezen voegen naar de wet!'8 In dit verband bespreekt de brochure de bekende 'zwijgteksten', 1 Korinthe 11:3vv; 1 Korinthe 14:34,35; 1 Timotheüs 2:9-15. Hier grijpt Paulus terug op de scheppingsorde die vanuit het christelijk geloof tot bloei wil komen. Het gaat mis wanneer Gods orde wordt losgelaten. Dat gebeurt waar de vrouw in gezag-

5 Mannelijk en vrouwelijk, 21.

6 Mannelijk en vrouwelijk, 25.

7 Mannelijk en vrouwelijk, 25-26.

8 Mannelijk en vrouwelijk, 28. 
volle verkondiging gezag over de man gaat uitoefenen. 'De genadestroom blijkt te willen bloeien in de bedding van Gods ordening bij de schepping. De verlossing heft de schepping niet op, maar brengt haar terug - en dan vanuit de grote rijkdom van het kruis. ${ }^{9}$

(2) Er wordt een stevig accent gelegd op de betekenis van de ambten. 'Het charismatische behoeft de stevigheid van de opzienerstaak.'10 De opzieners, oudsten en diakenen blijken de ruggengraat van de gemeente te vormen, omdat zich in hen het apostolisch gezag voortzet om de gemeente niet stuurloos te laten. De ambten representeren Christus naar de gemeente toe. Bij allerlei historische inkleuringen en ontwikkelingen door de eeuwen heen zien we toch telkens een consistente lijn naar voren komen: 'de eeuwen door was er een zekere opzienerstaak, een vorm van regeren die geestelijk en herderlijk bedoeld is, waar gezag, leiding en opzicht aan verbonden is.' ${ }^{11}$ De ambten zijn als het skelet van het lichaam, terwijl de gaven van de Geest als de bloedbanen in dat lichaam zijn. Waar nu het mannelijke vanuit de scheppingsorde staat voor leiding en gezag, ligt het voor de hand dat mannen tot de dienst van het ambt geroepen worden (er zou wel plaats zijn voor de vrouwelijke diaken wanneer de diakenen geen zitting zouden hebben in de kerkenraad). Niet dat de mannelijke ambtsdrager de mannelijke Christus vertegenwoordigt. Tegenover Christus is heel de gemeente vrouwelijk: mannen en vrouwen samen zijn in het geloof de bruid van Christus. Maar het gaat hier om de representatie van het anders-zijn van Christus (dat Hij niet uit het midden van de gemeente opkomt), van het goddelijk initiatief van de genade waaraan de gemeente als bruid haar existentie te danken heeft.

(3) Voor de kerkgeschiedenis geldt: 'Het niet toelaten van de vrouw tot een kerkelijk ambt ging geheel samen met een beleving van de gelijkheid van man en vrouw in Christus.' 12 Theologisch is verder van belang dat God zich als Vader, niet als Moeder openbaart en dat Hij mens wordt als man, niet als vrouw. Terecht wordt opgemerkt dat we over God niet zomaar mogen denken vanuit ons geslachtelijk onderscheid van man en vrouw. God als geeste-

9 Mannelijk en vrouwelijk, 31.

10 Mannelijk en vrouwelijk, 34.

11 Mannelijk en vrouwelijk, 35.

12 Mannelijk en vrouwelijk, 38. De brochure Geroepen vrouw stelt echter: 'Helaas hebben ook in de kerkgeschiedenis gezaghebbende figuren (vrijwel altijd mannen) meer dan eens te weinig oog gehad voor de vele gezichten van het de vrouw aangedane kwaad. Op die manier hebben ook christenen bijgedragen aan de onderdrukking van de vrouw.'(17) 
lijk Wezen overstijgt dit onderscheid immers. ${ }^{13}$ Maar als Vader is God hoger en anders dan het schepsel en als Man is Jezus Hoofd van alles. 'Zowel de Vadernaam als de menswording als een man heeft te maken met het beeld van God.' ${ }^{14}$ In het Vaderschap en het man-zijn leren we God als hoog, vol gezag, te erkennen. Datzelfde zien we vervolgens terugkeren rondom de ambten die bedoeld zijn om iets van het gezag van God te weerspiegelen, al wordt dit op dienende wijze ingevuld.

\section{Geroepen vrouw}

De brochure Geroepen vrouw is van meet af aan bedoeld om in samenhang met Man en vrouw schiep Hij hen gelezen te worden. Het gaat hierin om een nadere uitwerking van de bijzondere plaats en roeping van de vrouw in de gemeente en wel binnen de eerder geschetste principiële kaders. Hierbij wordt een aantal eigen accenten gelegd. Zo krijgt de charismatische structuur van de gemeente nadruk: 'de gemeente van Christus is een geestelijk mondige, rijk begaafde gemeente en de gaven dienen alle ruimte te krijgen.' ${ }^{15}$ Gelovigen zijn geen leken die lager op de hiërarchische ladder staan dan de 'geestelijkheid', maar ze vormen het door God geroepen volk dat haar opdracht in de wereld vervult. Er behoort geen scherpe scheiding te zijn tussen ambt en charisma, wel een heldere onderscheiding: de ambtsdragers geven leiding aan de gemeente, de overige broeders en zusters geven op allerlei manieren leiding in de gemeente (zondagsschool, jeugdclub, catecheseteam, zendingscommissie, commissie van beheer et cetera). Het ambtelijk leidinggeven aan de gemeente concentreert zich op het bewaken en bewaren van de identiteit van de gemeente in trouw aan het Woord van God en aan het belijden van de kerk der eeuwen.

Vanuit een evenwichtig christologisch-pneumatologisch uitgewerkte ecclesiologie kan zowel aan de fundamentele betekenis van de ambten als aan de charismatische begaafdheid van de gemeente optimaal recht worden gedaan. 'De ambtsdragers zweven volgens het gereformeerde kerkrecht niet op een hoger niveau boven de gemeente, maar maken zelf voluit deel uit van de gemeente uit wier midden ze tot hun ambt geroepen zijn.'16

Kerkenraden worden gestimuleerd om de gaven van vrouwen in de gemeente op te merken en op verschillende werkvelden binnen de gemeente in te zetten (diaconaal, catechetisch, pastoraal, missionair en zeker ook in het

13 Mannelijk en vrouwelijk, 48.

14 Mannelijk en vrouwelijk, 48-49.

15 Geroepen vrouw, 13.

16 Geroepen vrouw, 9. 
gezin als 'kleine gemeente'). Dit vraagt om intense aandacht voor gemeenteopbouw. Daarbij hoort het in kaart brengen van aanwezige gaven én het scheppen van voldoende ruimte tot ontplooiing daarvan door zowel vrouwen als mannen, jongeren als ouderen. Er zijn niet alleen voldoende mensen nodig voor de taken, maar ook voldoende taken voor de mensen. En dat niet om met gaven te schitteren, maar om er juist mee te dienen. Tegenover een werelds ideaal van zelfontplooiing zijn hier evenzeer voor mannen als voor vrouwen dienstbaarheid en zelfverloochening sleutelwoorden.

\section{Kritiek van Jansen}

Jansen heeft scherpe kritiek op de inhoud van de brochure Man en vrouw schiep Hij hen. ${ }^{17}$ In deze paragraaf halen we de voornaamste bezwaren uit Jansens artikel naar voren en geven daar op onze beurt enkele kritische overwegingen bij.

De kritiek spitst zich allereerst toe op de hermeneutische functie van het denken in 'scheppingsordeningen'. Dit is een hermeneutisch model dat als zodanig leidt tot een selectie van bijbelse aanwijzingen, een samenhang suggereert en sturing biedt aan het verstaan van de Schrift. Op zich is dit onontkoombaar. Zijn protest richt zich echter op de misplaatste toepassing van de 'scheppingsordeningentheologie' op het punt van de man-vrouwverhouding. Hierbij worden sterk cultureel-contextueel bepaalde visies op 'essenties' van mannelijkheid en vrouwelijkheid voorgesteld als onveranderlijke gegevens vanuit de schepping. Zo wordt een onderdrukkende en discriminerende status-quo van een fraaie strik voorzien.

Jansen blijkt overigens wel open te staan voor het Anliegen van de 'scheppingsordeningentheologie'. Hij suggereert een interessante kwalificatie van het denken over 'scheppingsorde' door in navolging van Heleen Zorgdrager opnieuw een biologische, genetische basis van 'genderpatronen' te erkennen, maar dan in het kader van een evolutionaire verklaring. Onze vraag is hierbij: welk verschil maakt dit ten opzichte van de klassieke herleiding van de 'scheppingsorde' tot de wil van een persoonlijk God? De suggestie is dat men hiermee de 'harde' wetenschappelijke gegevens aan zijn zijde heeft, maar sluipt er niet evengoed wensdenken binnen als het gaat om de verbreiding van diversiteit en gelijkwaardigheid? In elk geval is het zo dat er een fysieke basis ligt onder menselijke gedragingen en verhoudingen. Er is een genetische aanleg voor verschillende seksuele oriëntaties en bepaalde psychische patronen zijn

17 Jansen geeft er geen blijk van de tweede brochure te hebben gelezen. 
typerend voor meerderheden van mannen respectievelijk vrouwen. De scheppingsleer krijgt hier een handreiking van de biologie. Jansen noemt deze overwegingen in het kader van zijn bestrijding van de gedachte dat gelijkberechtiging van mannen en vrouwen genderdiversiteit zou miskennen vanuit 'gelijkheidsdenken'. Gelijkwaardigheid krijgt immers juist gestalte door meer recht te doen aan diversiteit.

Uitgaande van Gods wil als startpunt en richtpunt pleit Jansen voor gesprek met andere (sociale) wetenschappen. Om eigenheid en verbondenheid van mannen en vrouwen invulling te geven is dat inderdaad nodig. Alleen is een methodisch probleem dat deze wetenschappen minstens zo vol interpretaties, aannames en belangen zijn als de uitleg van de Bijbel. Het is een illusie om daarvan eenduidige resultaten te verwachten, terwijl intussen het verstaan van de Schrift met veel vraagtekens wordt omgeven.

De tweede spits van Jansens kritiek betreft de door hem gesignaleerde 'paternalistische ambtstheologie.' Onzes inziens is Jansens vraagstelling aan het begin van zijn paragraaf over ambtstheologie wat suggestief en sorteert deze al voor op het label 'paternalistisch'. Dat vrouwen als zodanig 'ongeschikt' zouden zijn voor het ambt is van een andere orde dan de opvatting 'het ambt komt vrouwen niet toe' (op nader aan te geven gronden). Onze bewering in dit artikel is dat de klassiek-gereformeerde de eerste stelling niet nodig heeft, en zich langs de tweede lijn beweegt.

Helaas hanteert Jansen in dit verband nogal wat onvolledige argumenten, bijvoorbeeld om te betogen dat onze huidige ambten niet rechtstreeks uit de Bijbel stammen (wie zou dat willen beweren?) en dat de recent waarneembare herwaardering van het predikambt meteen vraagt om verrijking met vrouwelijke inbreng.

Verder valt ons op dat Jansens redenering er kennelijk van uitgaat dat het ambt hoger staat dan andere bedieningen en charisma's. Van deze hiërarchische geleding nemen we afstand omdat we niet in een massieve, ongedifferentieerde hantering van het begrip 'ambt' willen blijven steken. Vanuit het Nieuwe Testament bezien vormen 'ambt' en 'charisma' geen tegenstelling, maar zijn ze juist in hun onderling reliëf op elkaar aangewezen voor het gezond functioneren van de gemeente. Het zou naar onze overtuiging een stap vooruit zijn wanneer het gesprek over de inzet van geestesgaven van vrouwen en mannen niet uitsluitend via de massieve vraag naar 'het ambt' wordt gevoerd.

Ten aanzien van de 'zwijgteksten' onderneemt Jansen nauwelijks een poging tot serieuze exegese. Hij verwijt zijn opponenten miskenning van de culturele en historische contextualiteit van zowel de Bijbel als de eigen theologie en hermeneutiek. Hierdoor zou de kerk een 'archaïsch relict uit patriarchale tijden' dreigen te worden. 
In de bespreking van Galaten 3:28 presenteert Jansen een aantal belangrijke inzichten die inderdaad het belang van de onderscheiden 'identiteit' van man of vrouw relativeren. De argumentatie verzandt echter wanneer de beperkingen die dezelfde Paulus van Galaten 3 op andere plaatsen aan het optreden van vrouwen oplegt uitsluitend aan het publieke recht van de toenmalige maatschappij worden verbonden. Dat is nu juist wat moet worden aangetoond: hoe hangen de gronden voor de diverse apostolische instructies met elkaar samen? Bij 1 Korinthe 14:34,35 (een tekst die al te gemakkelijk als latere interpolatie onschadelijk word gemaakt) en 1 Timotheüs 2: 9-15 ziet Jansen een botsing optreden met 'de impuls van Galaten 3:28'. Deze teksten tonen volgens hem aan hoe de macht van de culturele context heerst boven het bevrijdende nieuwe inzicht dat Paulus eerder heeft geformuleerd. Het is onzes inziens karikaturaal om wat deze teksten beogen te parafraseren als 'de vrouw die geen kinderen baart wordt weer tweederangs en onderwijs geven is er ook niet meer bij.' Het is veel vruchtbaarder om te zoeken naar de consistentie van Paulus' woorden (en daarin van de mening van de Heilige Geest) wanneer we ontegenzeggelijk spanning ervaren tussen Galaten 3:28 en 1 Korinthe 11:5 enerzijds en 1 Korinthe 14:34,35 en 1 Timotheüs 2:9-15 anderzijds.

Interessant is wat Jansen opmerkt over het verband tussen de 'zwijgteksten' en de missionaire drive van de apostelen. Ze kunnen worden gezien als symptoom van inculturatie in een patriarchale cultuur, bedoeld om drempels voor buitenstaanders weg te nemen. In onze totaal veranderde eigentijdse context van volledige maatschappelijke gelijkberechtiging zouden deze teksten ons dan juist moeten stimuleren een heel andere richting in te slaan, namelijk de inculturatie van het evangelie van een nieuwe gemeenschap in Christus' naam. Jansen vraagt zich af welk missionair belang gediend kan zijn met een 'hardnekkig vasthouden aan theologische constructies'.

Wij vragen: wat als het nu niet gaat om theologische constructies, maar om een volgehouden poging de gehele Schrift recht te doen? Dan gaan we in het apostolische spoor door niet alleen cultuurvolgend, maar ook cultuurkritisch en cultuurvormend bezig te zijn. De zwijgteksten zijn immers ook niet louter cultuurvolgend, maar wel degelijk cultuurkritisch in bijvoorbeeld de afwijzing van toenmalige gnostische ideeën die haaks stonden op de dankbare acceptatie van seksualiteit, huwelijk en gezinsvorming ('maar de vrouw zal in de weg van het baren van kinderen zalig worden, als zij blijft in geloof, liefde en heiliging, gepaard met bezonnenheid', 2 Tim. 2:15). Hoe wil Jansen inhoud geven aan het cultuurkritische element? De stelling dat ook in een gewijzigde praktijk de 'zwijgteksten' hun relevantie behouden, wordt door hem niet waargemaakt. Van een werkelijk tegengeluid tegen maatschappelijke patronen blijft hier weinig over. 
In zijn slotbeschouwing trekt Jansen de lijnen nogal grof. Opnieuw blijft de optie om bij erkenning van de fundamentele gelijkwaardigheid ook te spreken over functionele differentiatie in taken en verantwoordelijkheid van mannen en vrouwen, en daaruit conclusies te trekken voor de ambten in de kerk, buiten beschouwing. De discussie over 'gelijkwaardigheid' en 'gelijkheid' blijft helaas een semantisch spel wanneer er geen ruimte is voor de optie om naast fundamentele gelijkwaardigheid ook te spreken over functionele differentiatie.

\section{Gespreksagenda}

We zijn Jansen en de overige ondertekenaars van het genoemde appèl erkentelijk voor hun aanzet tot een hernieuwd gesprek over 'de vrouw in het ambt'. Met het oog op dat gesprek reiken we een aantal naar ons besef relevante en onmisbare punten aan.

\section{Welk gezag kennen we toe aan de Heilige Schrift?}

Wij kunnen ons geheel vinden in wat in de brochure Mannelijk en vrouwelijk schiep Hij hen hierover wordt gezegd. 'Wie de heilige Schrift hoort, verneemt de stem van de levende God.'18 Daarom dient de Schrift gelezen te worden vanuit een existentiële houding van ootmoed en gehoorzaamheid. De brochure noemt een vijftal fundamentele hermeneutische regels die de uitleg van de Schrift in goede banen kunnen leiden: (1) De Schrift heeft - in haar geheel - goddelijk gezag; (2) Christus is het hart van de Bijbel; (3) Het Oude Testament lezen we in het licht van het Nieuwe Testament; (4) We leggen de Schrift uit in onderlinge samenhang; (5) We onderzoeken nauwkeurig de cultuur van toen en nu. 'De tekst als geheel blijft echter de drager van Gods boodschap, met haar culturele gewaad. ${ }^{19}$ Het komt er voor de kerk op aan de Heilige Schrift 'inclusief haar taalkleed en cultureel gewaad als Gods Woord te rekenen en er zo nederig voor te buigen dat Gods boodschap in het geheel van de tekst kan doorkomen.' ${ }^{20}$ De Schrift heeft met haar veelheid van onderwerpen gezag en juist zo is zij een levensvernieuwende en cultuurvormende kracht. De genoemde vijf criteria leiden niet per definitie tot één uitkomst in een vraagstuk als 'vrouw en ambt', maar ze bepalen wel de fundamentele richting waarin ons verstaan van de Schrift zich heeft te bewegen. Zo is er in het hermeneutische proces een levendige pendelbeweging, waarbij de Schrift 
voorrang heeft. Waar die voorrang aan de Schrift wordt ontzegd, kan Gods Woord niet of nauwelijks meer als een werkelijk tegenover functioneren en wordt de kerk louter cultuurvolgend. De Schrift wordt dan 'in het harnas van onze culturele lijnen gestopt.'21

Jansen stelt ten aanzien van wat er in het hermeneutisch procedé met teksten uit de Bijbel gebeurt: 'Zo worden zij Woord van God, viva vox Dei'. Inderdaad dienen we ons er altijd weer van bewust te zijn dat we meerdere hermeneutische brillen dragen bij het lezen van de Schrift. Juist daarom is het in de kerk van onschatbare waarde om elkaar te blijven bevragen op (verborgen) vooronderstellingen en (vaak onbewuste) belangen. Toch rijzen hier bij ons grote vragen. Selectie, ordening en interpretatie van de schriftwoorden bevinden zich aan de kant van óns ontvangen en verwerken van Gods geopenbaarde wil. Dit verstaansproces zal altijd teruggekoppeld moeten worden naar het concrete getuigenis van de Schriften. We hebben principiële moeite met het onderscheid tussen de letter van de Schrift die op zichzelf dood zou zijn en de viva vox Dei die pas gehoord zou worden binnen de kerk als lees- en interpretatiegemeenschap. Dit doet onzes inziens tekort aan de autopistie van de Schrift die zoals ze ons van Godswege gegeven is zelf als viva vox Dei dient te worden getypeerd. ${ }^{22}$ Het is zeker waar dat deze levende stem van God vervolgens alleen recht verstaan wordt binnen de door de Geest geleide leesgemeenschap van de kerk die het Woord leert toepassen in verbondenheid met de Kerk der eeuwen én in haar eigen specifieke context. Het gezag van de Schrift gaat ook dan echter niet over op het gezag van onze eigen theologische interpretaties. We maken het niet mee dat de Bijbel waar het gaat om culturele en historische contextualiteit op één lijn wordt gezet met theologie en hermeneutiek. De Bijbel is Gods eeuwige Woord zoals het is ingegaan in de tijd. Van deze theopneuste Schrift belijden we dat elke tekst (pasa graphè, 2 Tim. 3:16) boven de cultuur en geschiedenis uitstijgt en naast een tijdbetrokken component een blijvend gezaghebbende kern bevat. Waar dit niet wordt erkend, kan hermeneutiek worden ingezet als breekijzer in plaats van als rekenschap. Vanuit een gereformeerde opvatting over het schriftgezag, zoals verwoord in art. 5 en 7 van de Nederlandse Geloofsbelijdenis, gaat het niet aan om aspecten van het bijbelse spreken geheel aan een oosterse, paternalis-

21 Mannelijk en vrouwelijk, 17.

22 Zie voor de autopistie van de Schrift H. van den Belt, The Authority of Scripture in Reformed Theology: Truth and Trust, Leiden 2008 en voor hermeneutische bezinning op basis van deze autopistie Jan H. van Doleweerd, Viva Vox Dei. Over de betekenis van de autopistie van de Schrift voor zending en Schriftuitleg in de gereformeerd bevindelijke traditie, Apeldoorn 2012. 
tische cultuur toe te schrijven. We zijn geroepen telkens weer te buigen voor de Schrift zelf.

\section{Hoe beroepen we ons op de schepping?}

We willen zelf niet eenzijdig focussen op de discussie rond scheppingsordeningen (of wellicht beter: mandaten, omdat het begrip 'scheppingsordeningen' erfelijk belast is). Theologisch gezien is het debat breder en wordt het vraagstuk in diverse contexten op een steeds iets andere manier aan de orde gesteld. Zelf vatten we de relatie man/vrouw meer op als een 'positief gebod' dan als een 'natuurlijke orde' die ondubbelzinnig ontologisch (biologisch, psychologisch) gefundeerd is. De man is niet op basis van zijn biologische of psychologische kenmerken meer geschikt voor het ambt dan de vrouw. Indien er al - toch altijd generaliserend - transculturele typische eigenschappen zouden kunnen worden geformuleerd, dan is het nog altijd zo dat de Bijbel deze als zodanig niet aanwijst. Wij voor ons zouden dus allerminst willen beweren dat er typisch vrouwelijke eigenschappen zijn die vrouwen per definitie ongeschikt maken voor het ambt. Een beroep op vermeende onvoldoende intellectuele of fysieke capaciteiten is volstrekt misplaatst. Dat geldt trouwens ook voor de idee dat het ambt de mannelijkheid van Christus zou moeten representeren.

De hoofdlijn van de argumentatie van tegenstanders van de toelating van de vrouw tot de ambten zou moeten berusten op een 'positief' (dus niet per natuurwet 'noodzakelijk', maar contingent) gebod dat uit de Schrift wordt afgelezen. De bekende 'zwijgteksten' worden dan zo verstaan dat God het kennelijk niet gewild heeft dat vrouwen in specifieke, leidinggevende en onderwijzende functies binnen de kerk actief zijn. Mogen we in de theologie doorvragen naar de ratio achter dit positieve voorschrift? In principe wel, al moet er rekening mee gehouden worden dat het ons niet altijd lukt deze ratio te doorgronden. De geldigheid van dat voorschrift staat of valt daar niet mee.

3. Kunnen we met bijbels recht spreken over 'regeermacht' van de ambten? Of is die term in wezen ongeschikt?

De ambten zijn door Christus aan de gemeente gegeven om haar dienend leiding te geven. Het ministerium is diakonia. Hier volgen we de brochure Geroepen vrouw. Te midden van alle charismata die de Geest onder de gelovigen $(\mathrm{m} / \mathrm{v})$ uitdeelt, hebben de ambten een eigen positie vanuit een specifieke verantwoordelijkheid. Als zodanig zijn de ambten niet 'hoger' dan andere bedieningen. Ze vervullen wel een eigen taak ten opzichte van de Geestbegaafde gemeente, door voeding, richting, samenhang en grensbewaking voor het geheel aan te brengen, en in die zin oefent 'het ambt' gezag en lei- 
ding uit over de gemeente, maar deze eigen positie van de ambten behoort geen hiërarchische invulling te krijgen in de zin van dominante machtsuitoefening en ongelijkwaardigheid.

Terecht wijst Jansen erop dat er in het Nieuwe Testament een royale spreiding is waar te nemen van diverse inzet van vrouwen in dienst van het evangelie. Dit betekent dat we bij de hedendaagse inrichting van het kerkelijk leven niet alles via 'het ambt' moeten spelen, maar dat de veelheid van gaven en bedieningen die zich in de apostolische gemeenten voordeden vraagt om creatieve doorvertaling voor de kerk vandaag. Daarbij realiseren wij ons dat er wisselwerking bestaat tussen 'bediening' en 'ambt', juist ook wanneer zusters in pastorale, onderwijzende en diaconale taken worden ingeschakeld. Er is veel voor te zeggen om het 'gezag' van het 'ambt' mede te verbinden aan het inhoudelijk optreden van degene die een ambt bekleedt. Dit maakt het ietwat gekunsteld om uitsluitend op formele wijze over het gezag van het ambt te spreken. Een wijze zuster die in persoonlijk pastoraat troost en vermaant, oefent geestelijk gezag uit, ook als zij geen ambt draagt.

De eerlijkheid gebiedt te zeggen dat in 'traditionele' kerken en gemeentes de 'complementariteit' van mannen en vrouwen, die de inzet van vrouwen met hun gaven op eigen plek royaal mogelijk maakt, zelden tot bloei komt. Dat roept de vraag op in hoeverre er werkelijk oog is voor de strekking van het fundamentele apostolische woord in Galaten 3. Hoe komt het dat de gelijkwaardigheid van de vrouw die wel beleden werd toch in de praktijk niet of nauwelijks gehonoreerd is? Het gesloten houden van de ambten wordt door menigeen als een signaal gezien dat vrouwen toch minder in tel zijn. Hierbij zien we dat cultureel bepaalde inzichten een goede doorwerking van de bijbelse grondlijn hebben verhinderd. Hier wordt ons een spiegel voorgehouden om onszelf kritisch in te beschouwen. Inderdaad zijn maar al te vaak cultureel bepaalde verschijnselen en verhoudingen met een ondoordacht beroep op scheppingsordeningen sacrosanct verklaard. Uiterste zorgvuldigheid is hier geboden. Daardoor is de vrouw onrecht aangedaan en is zij in de kerkelijke praktijk op grote achterstand komen te staan. Gelukkig hebben veel begaafde christenvrouwen hun eigen weg gevonden om hun gaven met vrucht en met vreugde in te zetten. Niettemin is het urgent om er alles aan te doen deze achterstand weg te werken. Omgekeerd is evenzeer kritisch zelfonderzoek nodig ten aanzien van het volgen van denkwijzen die vandaag dominant zijn, zoals het emancipatoire gelijkheidsdenken en de opvatting dat 'alle theologie een sociaal construct' is. Theologie die haar naam verdient, is ten principale meer dan een sociaal construct, omdat zij horig is aan Gods Woord dat over alle tijden gaat. Dat sluit niet uit dat elke theologie contextueel bepaald is. Maar als dat laatste het enige is dat gezegd kan worden, blijft slechts een 
kale strijd tussen groepen en belangen over. Goede theologie heeft steeds de culturele vanzelfsprekendheden ter discussie gesteld, zoals bij slavernij ${ }^{23}$ en de positie van de vrouw ${ }^{24}$ ook uit de geschiedenis kan worden aangetoond. Dat met een beroep op theologische noties misstanden zijn goedgepraat, is een misbruik dat het goed gebruik niet opheft.

4. Laten we de zwijgteksten werkelijk uitpraten of leggen we ze het zwijgen op? Voor het antwoord op die vraag is 1 Korinthe 11 een intrigerend bijbelgedeelte. Hoewel niet gerekend tot de directe 'zwijgteksten' in de discussies over 'vrouw en ambt', is het wel een voorbeeld van apostolische instructies voor de praktijk (hoofdbedekking) waaraan diepere inzichten over de verhouding van man en vrouw ten grondslag liggen. Terwijl de concrete aanwijzingen voor haardracht en hoofddeksel nog als tijdbepaalde 'aankleding' zouden kunnen worden aangemerkt, mogen wij ons niet zomaar van de achterliggende overwegingen losmaken. Enerzijds brengt Paulus een diepe eenheid en een wederzijdse afhankelijkheid aan het licht: "Evenwel is de man niet zonder de vrouw, en de vrouw niet zonder de man, in de Heere" (1 Kor. 11:11, HSV). Anderzijds noemt Paulus de man 'het hoofd van de vrouw', evenals Christus het hoofd van de man is, en God het hoofd van Christus. Naast deze 'getrapte' relaties spreekt Paulus ook in termen van 'beeld' en 'heerlijkheid'. Dit maakt duidelijk dat er niet slechts sprake is van boven- en onderschikking, maar van een over en weer in de ander herkend en bevestigd worden. Het komt ons voor dat de wederzijdse 'afspiegelingsstructuur' van beeld en heerlijkheid alleen werkt wanneer er verschil is. Mannen en vrouwen zijn geen klonen of kopieën, maar mogen in hun verschil en in hun gezamenlijkheid het beeld van God vertonen. Wanneer Paulus in verband met de orde in de christelijke gemeente (1 Kor. 14, 1 Tim. 2) vraagt om hupotassein is dat onzes inziens niet alleen als culturele accommodatie op te vatten. In dat verband: de 'tweelingstrategie' in de uitleg van 1 Korinthe 11 die door dr. Jansen aan Miroslav Volf wordt ontleend klinkt wel mooi, maar hoe zorg je dat het ene (het bewaren van onderscheiden genderidentiteiten) niet verdwijnt in het andere (het construeren van een complexe nieuwe identiteit van wederzijdse insluiting van de ander)? Dat blijft bij Volf en bij Jansen vaag: dialectiek en transcendentie leiden tot

23 Theologische kritiek op het instituut slavernij is al in de Middeleeuwen te vinden, en de 19e-eeuwse beweging voor afschaffing van de slavernij werd voor een aanzienlijk door godsdienstige overtuiging gedreven.

24 Denk aan de fundamentele beschouwing van Gisbertus Voetius in zijn Politica ecclesiasti$c a$, waar hij het tegenover eerdere stemmen uit de traditie consequent voor de menselijke waardigheid van de vrouw opneemt, 
een nieuw type mens. Is het daarbij de bedoeling dat verschillen wegvallen of dat verschillen tot verrijking leiden?

5. Welke waarde kennen we toe aan het missionaire motief?

Het missionaire motief is zeker relevant en dringt tot zelfonderzoek in gemeenten waar de plaats van de mannelijke kerkenraad sterk geaccentueerd wordt en de vrouwelijke inbreng in de erediensten en in het beleid minimaal is. Hoe komt hier de krachtige impuls van Galaten 3:28 nog tot uiting? Aan de andere kant mag missionair bewustzijn er niet toe leiden dat het zout zijn zoutende kracht verliest.

Jansen vult de notie van 'Christusrepresentatie' als kern van het ambt in met het dragen van een 'nieuwe humaniteit'. Dat blijft wel wat steriel en suggestief. De verwijzing naar 'lichaam' en 'Hoofd' in Efeze 4 met betrekking tot het geheel van de christelijke kerk is aantrekkelijk, evenals de lijn naar de analogie tussen Christus/gemeente en man/vrouw in Efeze 5. Alleen is de stelling dat Efeze 5 draait om wederzijdse onderschikking aanvechtbaar, en moet er ten minste ook recht gedaan worden aan de 'onverwisselbare eigenheid' die blijkens dit hoofdstuk aan man en vrouw toekomt. Alleen in die onverwisselbare eigenheid komt het samenspel van liefde en wederzijdse dienst op gang, waarin man en vrouw het geheim van Christus en zijn gemeente mogen weerspiegelen.

Al met al zijn we lang niet uitgepraat over de verhouding tussen reformatorische ambtstheologie en de waardigheid van de vrouw. In dit artikel hebben wij aangegeven waar naar ons inzicht de fundamentele noties liggen die niet zomaar kunnen worden opgegeven. Het gaat dan in ieder geval om (1) de eigenheid van mannen en vrouwen in hun onderlinge verhouding; (2) het karakter van de ambten en hun plaats in het geheel van gaven en diensten in de gemeente; (3) het gezag van de Bijbel als Woord van God voor alle tijden. Dit betekent niet dat de visie op deze drie kernpunten volledig dichtgetimmerd is. Er liggen vragen open die met een beroep op de Schrift op verschillende manieren beantwoord en beargumenteerd kunnen worden. Het gesprek hierover vraagt tijd, inzet, openheid, respect en vooral gebed om de leiding van de Heilige Geest die ons het Woord leert verstaan en toepassen in onze eigen context. 